\title{
Assessing direct and indirect economic impacts of a flood event through the integration of spatial and computable general equilibrium modelling
}

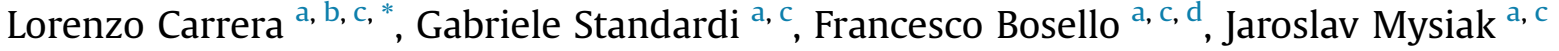 \\ ${ }^{a}$ Fondazione Eni Enrico Mattei, Isola San Giorgio Maggiore, 30124 Venice, Italy \\ ${ }^{\mathrm{b}} \mathrm{Ca}$ ' Foscari University of Venice, Dorsoduro 3246, 30123 Venice, Italy \\ ${ }^{c}$ Euro-Mediterranean Centre on Climate Change, Isola San Giorgio Maggiore, 30124 Venice, Italy \\ d University of Milan, Via Festa del Perdono 7, 20122 Milano, Italy
}

\section{A R T I C L E I N F O}

\section{Article history:}

Received 12 November 2013

Received in revised form

17 September 2014

Accepted 22 September 2014

Available online

\section{Keywords:}

Flood risk

Indirect impacts

Computable general equilibrium

Natural disasters

\begin{abstract}
A B S T R A C T
In this paper we developed and tested an integrated methodology for assessing direct and indirect economic impacts of flooding. The methodology combines a spatial analysis of the damage to the physical stock with a general economic equilibrium approach using a regionally-calibrated (to Italy) version of a Computable General Equilibrium (CGE) global model. We applied the model to the 2000 Po river flood in Northern Italy. To account for the uncertainty in the induced effects on regional economies, we explored three disruption and two recovery scenarios. The results highlight that: i) the flood event produces indirect losses in the national economic system, which are a significant share of the direct losses, and ii) the methodology is able to capture both positive and negative economic effects of the disaster in different areas of the same country. The assessment of indirect impacts, in particular, is essential for a full understanding of the economic outcomes of natural disasters.
\end{abstract}

() 2014 Elsevier Ltd. All rights reserved.

\section{Introduction and background}

Water-related extremes, such as floods and storms, account at the global level for the greatest share of natural disasters' inflicted economic damage and death toll (Jonkman and Kelman, 2005; Kunreuther and Michel-kerjan, 2007; United Nations International Strategy for Disaster Reduction Secretariat, 2009). In Europe, according to NatCatService (MunichRE, 2010), 80 percent of the economic losses caused by natural disasters that occurred during the period 1980-2009 were related to hydro-meteorological events (EEA, 2010). Hydrological events only (i.e. flood and wet mass movements) account for 25 percent of the overall losses in the 32 European Environmental Agency (EEA) Member States, estimated as 414 billion Euro over the period 1980-2009 (in 2009 values) (EEA, 2010).

Growing population and capital density, unsustainable development, inappropriate land use and climate change, threaten to intensify natural hazards' risk with even more concerning

\footnotetext{
* Corresponding author. Fondazione Eni Enrico Mattei, Isola San Giorgio Maggiore 8, 30124 Venice, Italy. Tel.: +39 0412700 474; fax: +39 0412700412.

E-mail address: lorenzo.carrera@feem.it (L. Carrera).
}

consequences for the environment and societies (IPCC, 2012). Against this background the EEA warned that flood related losses will rise consistently in Europe (EEA, 2012). According to Feyen et al. (2012), which calculated the expected annual damage (EAD) from river flooding events in Europe, current EAD of 6.4 billion Euro may increase by 2100 to $14-21.5$ billion Euro (constant 2006 prices) depending on climate scenarios (Feyen et al., 2012). Under the medium to high emission scenario A1B Rojas et al. (Rojas et al., 2013) calculated that EAD might raise by the end of this century to around 97 billion Euro (constant 2006 prices undiscounted, considering both climate and socio-economic changes).

However, economic impacts of natural hazards are still poorly understood, particularly their indirect, wider and macro-economic effects. Typically estimates from the European Environmental Agency (EEA) (EEA, 2012) and global disaster databases (i.e. the EMDAT dataset managed by the Centre for Research on the Epidemiology of Disasters, the NatCatSERVICE dataset managed by Munich Reinsurance Company, and the Sigma dataset from Swiss Reinsurance Company) undervalue the full cost of disasters to societies and environment because most of the time they account for direct impacts only, with partial or incomplete consideration given to indirect, wider and macroeconomic effects. 
Several efforts have been made to assess indirect impacts of disasters on national and regional economies (Cochrane, 2004; Green et al., 2011; Messner et al., 2007; Okuyama, 2007; Przyluski and Hallegatte, 2011; Rose, 2004) using different methodologies. These include amongst others: post event economic surveys (Kroll et al., 1991; Molinari et al., 2014; Pfurtscheller, 2014), econometric models (Albala-Bertrand, 1993; Cavallo et al., 2012; Noy and Nualsri, 2007; Strobl, 2010), input-output (I-O) models (Hallegatte, 2008; Hallegatte et al., 2011; Henriet et al., 2012; Okuyama, 2014; Okuyama et al., 2004; Ranger et al., 2011), computable general equilibrium (CGE) models (Berrittella et al., 2007; Bosello et al., 2012, 2006; Haddad and Teixeira, 2013; Jonkhoff, 2009; Pauw, K. et al., 2011; Rose and Liao, 2005; Rose et al., 1997; Tsuchiya et al., 2007). Different methodologies have different advantages and disadvantages. Econometric models and post event surveys, if well specified and based upon data of a reasonable quality, can indeed quantify indirect effects on national/ local GDP of extreme events with high levels of accuracy and scarce uncertainty in the assessment procedure (Przyluski and Hallegatte, 2011). However they cannot describe the systemic economic channels through which they propagate within and between the economies affected. I-O and CGE models can do so (Hallegatte, 2008; Moffatt and Hanley, 2001; Okuyama, 2007; Rose, 2004). I-O models can reach a high analytical specificity, they can represent urban contexts as well as even smaller economic entities like natural parks or cities, but then they are usually missing the effect on the overall economy. Moreover I-O models cannot assess the impacts on the supply side, and do not allow for flexibility in the economic system which is indeed a characteristics of CGE models (Hallegatte, 2008). CGE models are able to capture the feedback effects from the macro-economic context on the "markets" initially concerned (Rose, 2004). Furthermore, in general equilibrium approaches the use of consistent accounting methodology for capturing economic flows overcome the problems of 'doublecounting', often affecting the evaluation conducted through the application of partial equilibrium (Pauw, et al., 2011). CGE models also offer in principle the possibility to conduct simulated counterfactual analyses, comparison between what happened and what would have happened in the absence of the catastrophic event. Nonetheless, CGE models have several limitations. They assume perfect markets and they are not able to capture non-market values (Pauw, et al., 2011). Another important limitation of CGE models is their "coarse" investigation unit, usually the country. This may allow analysis of aggregated events or trends, but makes local analyses particularly challenging, especially for small to medium disasters.

Against this background, in this paper we propose the combination of a spatially based analysis with a CGE model, regionally calibrated to the Italian macro-regions North, Centre and South (Standardi et al., 2014). Our sub-national version of the global CGE model allows to assess the regional impacts (at sub-national level), whilst maintaining the global scale of the economic system (e.g. global trading, international exports and imports, etc.).

Our aim is to couple the high resolution of spatial analysis (Zerger, 2002) with the CGE models' systemic ability to capture economic interaction (Bosello et al., 2012, 2006; Liang et al., 2014), without pushing the CGE aggregation need too far to loose completely local specificities. We then apply our methodology to estimate the economic impacts at the sub-national and national level of a flood event that occurred in Northern Italy in October 2000. At country level the outputs of the model provide an indirectdirect losses ratio of $0.19-0.22$. The model is also able to unravel the wider impact of the flood into differentiated effects in sub-national economies. Thus the indirect losses in the North are partially compensated by (small) economic gains in non-affected areas
(Centre and South) because of the interconnectivity of the economic system, the mobility of productivity factors and substitution of goods. The propagation of impacts beyond national border is negligible and the EU level GDP is in practice unaffected.

The paper unfolds as follows: Section 2 briefly reviews the case study area and the flood event; Section 3 provides a comprehensive discussion on the conceptual framework and methodology, a description of the sample data and the integrated model; Section 4 presents and discusses the results; Section 5 concludes the document providing a critical review of the outcomes, in the broader context of flood impact assessment and disaster risk management.

\section{Background information on the Po river October 2000 flood event}

The Po river is located in Northern Italy, which includes eight Italian regions: Piedmont, Aosta Valley, Liguria, Lombardy, Trentino Alto Adige, Veneto, Friuli-Venezia Giulia, Emilia-Romagna. The area produces around 77 percent of the national Gross Domestic Product (GDP), with Lombardy having by far the largest economy (21 percent of national GDP), followed by EmiliaRomagna with 9 percent, Piedmont with 8 percent and Aosta Valley with 0.3 percent. Because of the strategic importance of the area, this paper analyses the economic impacts of the Po river flood that occurred in October 2000 in Piedmont, Aosta Valley and other downstream regions in the Northern Italy. Between 13th and 16th October 2000, a series of extreme precipitation events, up to $600 \mathrm{~mm}$ in $48 \mathrm{~h}$ hit the Northwest of Italy leading to numerous inundations and landslides (Ratto et al., 2003; Regione Piemonte, 2000a, 2000b). The event is amongst the most significant that have occurred in Italy over the past decades. It caused 37 casualties and missing persons (27 in Italy and 10 in Switzerland) and economic damages of over 2.5 billion Euro, as reported by the Information System on Hydrogeological Disasters (IRPI), 5.2 billion Euro as reported by Guzzetti and Tonelli (2004) or 8.6 billion Euro as reported by the EM-DAT International Disasters Database (Centre for Research on the Epidemiology of Disasters CRED). More than 40,000 people were evacuated and at least 3000 lost their houses (Guzzetti and Tonelli, 2004). The flood hit more than 700 municipalities and almost all main cities of Piedmont and Aosta Valley. All economic sectors were severely impacted, either directly through structural damage or indirectly through business interruptions. The flood caused significant damages to industries, transport infrastructures and urbanized areas. It led to lifelines interruptions, cutting-off major highways, regional and provincial roads. Milan-Turin and Turin-Aosta highways were severely damaged. Bridges were destroyed resulting in temporal isolation of small and medium sized towns (Tropeano and Turconi, 2001). In several areas electricity, telecommunication, and drinking water supply services were interrupted for days - up to a week in Turin and other towns in the area (Tropeano and Turconi, 2001). In addition to hitting the constructed areas, the flood caused serious damages to agriculture affecting livestock, crop production, farm structures, and farming facilities (Farinosi et al., 2012).

\section{Methodology}

\subsection{Conceptual framework}

Our work aims to estimate the economic impacts of the Po river 2000 flood event. Because of the knowledge gap in indirect impact assessment, this paper focus on developing and testing an integrated methodology specifically aiming at their quantification. Therefore the direct impact assessment shall be considered 
instrumental to the indirect, and meaningful for comparison and validation of the outputs provided by the integrated spatial-CGE model. Hereinafter, we define the terminology used in the paper and the general conceptual framework with reference to relevant literature.

Meyer et al. (2013) divides the economic impacts of disasters in direct, business interruption, and indirect costs. Direct are the losses affecting humans, assets, property and any other objects in the areas that had physical contact with the flood (Merz et al., 2010; Meyer et al., 2013). Business interruptions are those losses that occur to business directly affected by the hazard. They are often referred as primary indirect damages because they are induced by the interruption of business activities. Indirect losses occur inside and outside the flooded area (Merz et al., 2010; Messner et al., 2007) and are caused by direct costs and/or business interruption costs (Przyluski and Hallegatte, 2011). Indirect impacts are prompted by the physical stock of capital which is damaged, transmitted through the inter-linkages of economic systems (Cochrane, 2004; Merz et al., 2010) and resulting in a disruption of economic flows (Rose and Liao, 2005; Rose, 2004). More in general at meso and macro scale, floods engender exogenous, internal or external (if international trade is affected) 'shocks' to economies, with far-reaching ripple effects. Beyond the direct structural damage caused by floods, the disaster-affected sectors are likely to curtail their activities and production, collect less revenues, lay-off staff, and postpone investments. These dynamics influence both the market and consumers' preferences. Direct losses set off a sequence of 'upstream' and 'downstream' reactions, which affect suppliers and customers. These ripple effects represent the indirect impacts of a disaster. Generally a flood event produces negative effects on the region directly affected but, on the larger scale, the event could produce positive and negative propagation effects in the economies of neighbouring and distant regions (Jonkhoff, 2009). The final economic effects of all these feedbacks and rebounds are in our analysis summarized by GDP changes assessed by the CGE model. GDP changes thus represent the indirect economic effects triggered by the flood event on the economic system. Indeed in the CGE jargon GDP costs are often referred to as 'indirect' or 'higher order' cost as they do consider price reactions, potential inter-market factor substitution and demand switches.

Summarizing, in this paper we consider direct impacts as the physical damage to the stock, which is a quantity at a single point time (Rose, 2004), and indirect impacts as the effect of a disaster to the flows, originated by the stock over time (Rose, 2004), or the aggregation of business interruption costs and indirect costs as defined in Meyer et al. (2013), which our model is not able to distinguish separately. Our analysis is a comparative static exercise adopting a one-year timeframe. In our setup the adjustment from the pre to the post-disaster economy is instantaneous. We acknowledge the fact that effects of disasters can extend over longer periods of time (Cavallo et al., 2012; Hallegatte, 2014) and that friction and inertia may affect the transition phases. Therefore our estimation of indirect impacts shall be considered as shortterm effects only and may underestimate losses. Table 1 provides the description of our conceptual framework.

\subsection{Integration of the spatial and CGE models}

The integrated model described in this paper (Fig. 1) is conceptually divided into three parts: i) the spatial analysis of the flood event for the estimation of direct impacts and affected areas $\left(\mathrm{km}^{2}\right)$ per land use class of Corine Land Cover 2000 (CLC2000); ii) the spatial-CGE integration part which produce the input (damage to the primary factors productivity per economic sector) to 'shock' the CGE model; iii) and the CGE model simulation which provides the indirect impacts.

Going backwards (right to left) in the methodological map (Fig. 1) we proceed as follows:

a) We estimate indirect impacts (production and GDP changes, monetary losses) by applying a 'shock' to the sub-national CGE model. The shock is provided by reducing (in percentage) the primary factors (capital, land and labour) productivity of the economic sectors in the flooded area (North), which are exogenous factors of the CGE model;

b) We derive changes in factors' productivity are derived (in the second part of the model) from the relation between land use and economic activities (described in 3.5.2). Hence, the percentage of flooded area per land use class in the North is translated into a reduction of capital and land productivity. The percentage of workers affected is translated into a reduction of labour productivity. For instance, if 10 percent of industrial areas in the North are flooded, we assume that 10 percent of the capital of the heavy manufacturing capital sector is damaged for a certain period of time. Assuming this period to be three months, the reduction to the capital productivity will be: $0.1 \times(3 / 12)$.

Equations (1) and (2) describe how we estimate the impacts to capital, land and labour:

$$
\begin{aligned}
& \operatorname{ICap}_{k}[\%]=\frac{\text { flooded } \operatorname{area}_{i}\left[\mathrm{~km}^{2}\right]}{\text { total } \text { area }_{i}\left[\mathrm{~km}^{2}\right]} \times \frac{\mathrm{D}}{365} \\
& \operatorname{ILab}_{k}[\%]=\frac{\text { affected } \text { workers }_{k}}{\text { total } \text { workers }_{k}} \times \frac{\mathrm{D}}{365}
\end{aligned}
$$

where:

$i$ is the land use class (or the sum of land use classes) associated to the economic sector $k$ (Table 5). ICap is the impact to the capital (and land), ILab is the impact to the labour, D is the duration of the impact in days.

Table 1

\begin{tabular}{|c|c|c|c|c|c|}
\hline \multirow{2}{*}{$\begin{array}{l}\text { Type of impact } \\
\text { (our definition) }\end{array}$} & \multicolumn{2}{|c|}{ Main literature reference } & \multirow[t]{2}{*}{ Assessment tool } & \multirow[t]{2}{*}{ Expected output } & \multirow[t]{2}{*}{ Scale of analysis } \\
\hline & Meyer et al., 2013 & Rose, 2004 & & & \\
\hline Direct & Direct cost & Stock of capital & $\begin{array}{l}\text { Spatial analysis with depth-damage } \\
\text { functions from Huizinga (2007) }\end{array}$ & $\begin{array}{l}\text { Physical damage to the stock } \\
\text { of capital represented by the } \\
\text { full replacement cost (Euro) }\end{array}$ & $250 \times 250 \mathrm{~m}$ \\
\hline Indirect & $\begin{array}{l}\text { Business interruption } \\
\text { cost, indirect cost }\end{array}$ & Flows & $\begin{array}{l}\text { Sub-national CGE model from } \\
\text { Standardi et al. (2014) }\end{array}$ & $\begin{array}{l}\text { Percent change in: i) production } \\
\text { per economic sector, ii) sub-national } \\
\text { (North, Centre, South), IT, EU, RoW GDP }\end{array}$ & $\begin{array}{l}\text { Sub-national areas } \\
\text { (North, Centre, South), } \\
\text { IT, EU, RoW }\end{array}$ \\
\hline
\end{tabular}

Summary of our conceptual approach and expected output. IT is Italy, EU European Union, Row Rest of the World. 


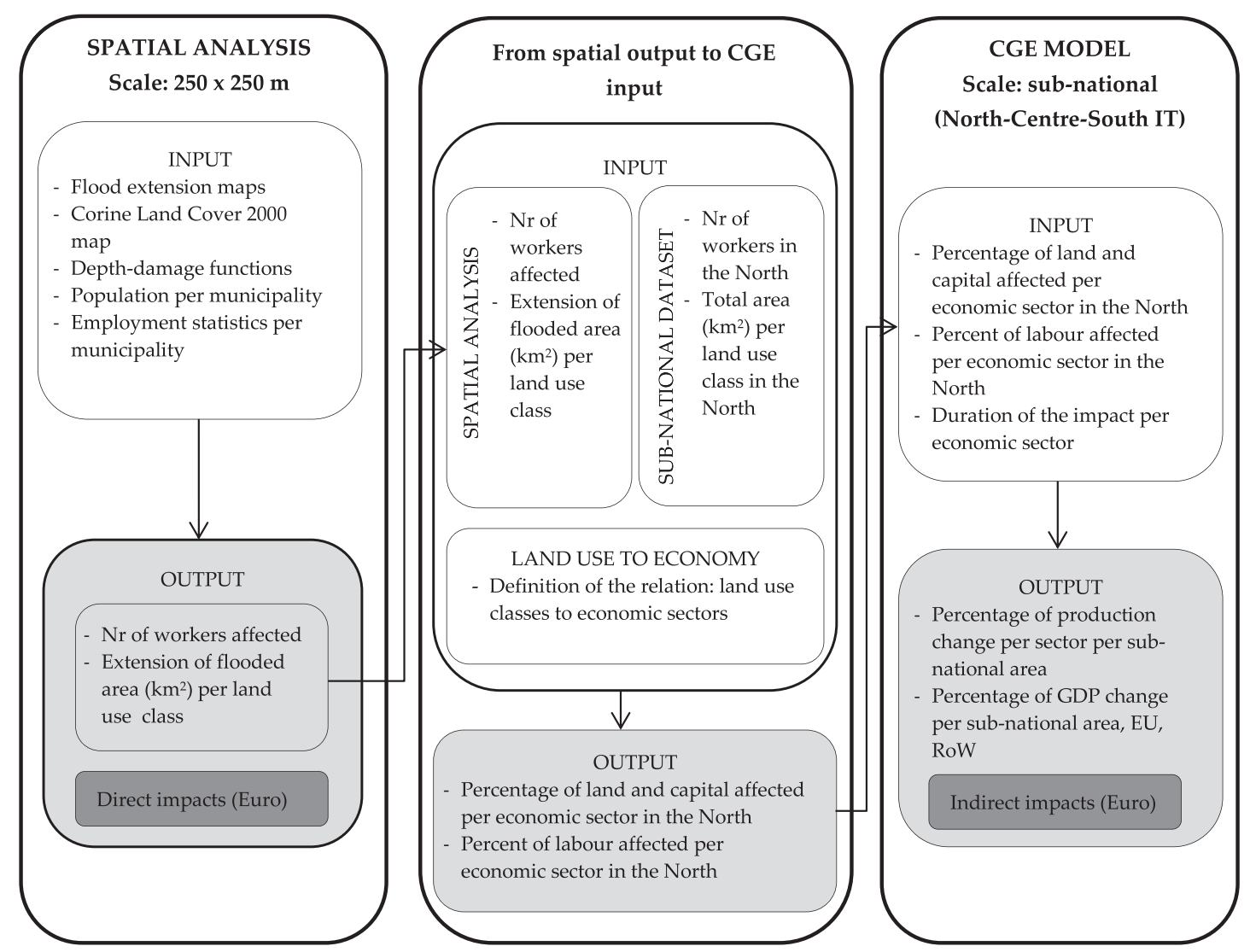

Fig. 1. Methodological map of the spatial-CGE integrated model.

We estimate workers at the municipality level and apply the impact to the Northern Italy economy. If a sector is associated with more than one land use class, the areas are summed up.

c) We estimate the impact using equations (1) and (2) via the spatial analysis. Flood extension maps are intersected with CLC2000 to calculate the flooded surfaces per land use class $\left(\mathrm{km}^{2}\right)$. CLC2000 is also used to calculate the total surface of each land use class in the North $\left(\mathrm{km}^{2}\right)$. The percentage of flooded area per land use class is the ratio between the two. We derive the number of affected workers from the National Census 2001 data at municipality level (from ISTAT). In order to consider the wider impacts of the flood, particularly on transport infrastructures and commuters, we assume that all workers belonging to a municipality intersecting the flooded area are fully affected. We use the same dataset to calculate the total workers in the North. As before, the ratio between affected and total is the percentage of affected workers. We estimate the direct economic impacts with depth-damage functions (Huizinga, 2007) on land use classes.

Table 2

Maximum damage values (Euro $/ \mathrm{m}^{2}$ in 2006 prices) and damage factor range (from a minimum of $1 \mathrm{~m}$ to a maximum of $6 \mathrm{~m}$ and over) per land use class for selected $\mathrm{EU}$ countries. Source: own elaboration on Huizinga, 2007.

\begin{tabular}{llllll}
\hline $\begin{array}{l}\text { Max damage } \\
\text { value - area }\end{array}$ & $\begin{array}{l}\text { Residential } \\
\text { building }\end{array}$ & Commerce & Industry & Road & Agriculture \\
\hline EU27 & 575 & 476 & 409 & 18 & 0.59 \\
Italy & 618 & 511 & 440 & 20 & 0.63 \\
Luxembourg & 1443 & 1195 & 1028 & 46 & 1.28 \\
Germany & 666 & 551 & 474 & 21 & 0.68 \\
Netherlands & 747 & 619 & 532 & 24 & 0.77 \\
France & 646 & 535 & 460 & 21 & 0.66 \\
Damage factor (range) & $0.4-1$ & $0.3-1$ & $0.3-1$ & $0.42-1$ & $0.55-1$ \\
\hline
\end{tabular}

Table 3

CGE model sectors.

\begin{tabular}{ll}
\hline CGE sectors & \\
\hline Grains and crops & $(1)$ \\
Livestock meat products & $(2)$ \\
Mining and extraction & $(3)$ \\
Processed food & $(4)$ \\
Textiles and clothing & $(5)$ \\
Light manufacturing & $(6)$ \\
Heavy manufacturing & $(7)$ \\
Utilities and construction & $(8)$ \\
Trade and communication & $(9)$ \\
Other services & $(10)$ \\
\hline
\end{tabular}

\subsection{Flood data sources}

The flood extension data sources used in this paper are: the Piedmont Region, the Agency for Environmental Protection of Piedmont Region (ARPA Piedmont), the Aosta Valley Region, the Po River Basin Authority and ARPA Emilia Romagna. Piedmont and

Table 4

Regions of the CGE model.

\begin{tabular}{ll}
\hline CGE regions & Description \\
\hline North & Aosta Valley, Emilia-Romagna, Friuli-Venezia Giulia, \\
& Liguria, Lombardy, Piedmont, Trentino-Alto Adige, Veneto \\
Centre & Lazio, Marche, Toscana, Umbria \\
South & Abruzzo, Apulia, Basilicata, Campania, Calabria, Molise, \\
& Sardegna, Sicilia \\
EU & Rest of the European Union \\
ROW & All remaining countries in the world \\
\hline
\end{tabular}


Table 5

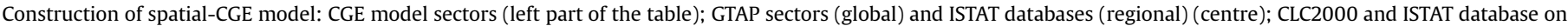
labour (right).

\begin{tabular}{|c|c|c|c|c|c|}
\hline \multirow[t]{3}{*}{ CGE model sector } & \multicolumn{2}{|c|}{ Regional calibration of the CGE model } & \multicolumn{3}{|c|}{ Estimation of the flood impact } \\
\hline & \multirow{2}{*}{$\begin{array}{l}\text { GTAP model } \\
\text { Sector }\end{array}$} & \multirow{2}{*}{$\begin{array}{l}\text { ISTAT databases } \\
\text { Sector }\end{array}$} & \multicolumn{2}{|l|}{ CLC2000 } & \multirow{2}{*}{$\begin{array}{l}\text { ISTAT database on } \\
\text { labour } \\
\text { Sector }\end{array}$} \\
\hline & & & name & Code & \\
\hline Grains and crops & $\begin{array}{l}\text { Cereal grains; Crops nec; Oil } \\
\text { seeds; Paddy rice; Plant-based } \\
\text { fibres; Processed rice; Sugar } \\
\text { cane; sugar beet; Vegetables; } \\
\text { fruit; nuts; Wheat }\end{array}$ & $\begin{array}{l}\text { Cereals; Citrus fruits; Flowers } \\
\text { and potted plants; Fruits; } \\
\text { Industrial vegetables;; } \\
\text { Legumes; Olives; Other woody } \\
\text { products; Pastures; Potatoes } \\
\text { and vegetables; Wine }\end{array}$ & Agriculture & 2.all subsets & Agriculture \\
\hline Heavy manufacturing & $\begin{array}{l}\text { Chemical, rubber, plastic prods; } \\
\text { Electronic equipment; Ferrous } \\
\text { metals; Machinery and } \\
\text { equipment nec; Metals nec; } \\
\text { Mineral products nec; } \\
\text { Petroleum, coal products }\end{array}$ & $\begin{array}{l}\text { Coke, refineries, chemical and } \\
\text { pharmaceutical; Manufacturing } \\
\text { of nonferrous minerals; Metal } \\
\text { and metallic goods production; } \\
\text { Wood, rubber, plastic factories } \\
\text { and other manufacturing }\end{array}$ & Industry and commercial & 1.2 .1 & Manufacture \\
\hline Light manufacturing & $\begin{array}{l}\text { Leather products; } \\
\text { Manufactures nec; Metal } \\
\text { products; Motor vehicles and } \\
\text { parts; Paper products, } \\
\text { publishing; Transport } \\
\text { equipment nec; Wood products }\end{array}$ & $\begin{array}{l}\text { Machinery and mechanical } \\
\text { manufacturing, electric and } \\
\text { optical equipment, } \\
\text { transportation; Paper, printing } \\
\text { and publishing; Tannery and } \\
\text { leather }\end{array}$ & Industry and commercial & 1.2 .1 & Manufacture \\
\hline Livestock meat products & $\begin{array}{l}\text { Animal products nec; Cattle, } \\
\text { sheep, goats, horses; Meat } \\
\text { products nec; Meat: cattle, } \\
\text { sheep, goats, horse; Raw milk; } \\
\text { Wool, silk-worm cocoons }\end{array}$ & $\begin{array}{l}\text { Eggs; Honey; Livestock; Meat; } \\
\text { Milk }\end{array}$ & Agriculture & 2.all subsets & Agriculture \\
\hline Mining and extraction & $\begin{array}{l}\text { Coal; Fishing; Forestry; Gas; } \\
\text { Minerals nec; Oil }\end{array}$ & Fishing; Forestry; Minerals & none & None & Extraction \\
\hline Other services & $\begin{array}{l}\text { Business services nec; } \\
\text { Dwellings; Financial services } \\
\text { nec; Insurance; PubAdmin/ } \\
\text { Defence/Health/Educat; } \\
\text { Recreation and other services }\end{array}$ & $\begin{array}{l}\text { Brokering; Domestic assistance; } \\
\text { Education; Healthcare and } \\
\text { other social services; Other } \\
\text { public, social and personal } \\
\text { services; Public administration } \\
\text { and defence; mandatory social } \\
\text { insurances; Real estate, rentals, } \\
\text { informatics, research and } \\
\text { development, other } \\
\text { professional and } \\
\text { entrepreneurial activities }\end{array}$ & Urban & $1.1 .1,1.1 .2$ & Services \\
\hline Processed food & $\begin{array}{l}\text { Beverages and tobacco } \\
\text { products; Dairy products; Food } \\
\text { products nec; Sugar; Vegetable } \\
\text { oils and fats }\end{array}$ & Food, beverages and tobacco & Industry and commercial & 1.2.1. & Manufacture \\
\hline Textiles and clothing & Textiles; Wearing apparel & Textile and wearing apparel & Industry and commercial & 1.2 .1 & Manufacture \\
\hline Trade and communication & $\begin{array}{l}\text { Air transport; Communication; } \\
\text { Sea transport; Trade; Transport } \\
\text { nec }\end{array}$ & $\begin{array}{l}\text { Hotels and restaurants; } \\
\text { Logistics, storage and } \\
\text { communications; Wholesale } \\
\text { and trading; vehicle, motorbike } \\
\text { and household appliance } \\
\text { repairing }\end{array}$ & Urban & 1.1.1, 1.1.2 & Transportation \\
\hline Utilities and construction & $\begin{array}{l}\text { Construction; Electricity; Gas } \\
\text { manufacture, distribution; } \\
\text { Water }\end{array}$ & $\begin{array}{l}\text { Construction; Production and } \\
\text { distribution of electric energy, } \\
\text { gas, steam and water }\end{array}$ & Transport infrastructures & $1.2 .2,1.2 .3,1.2 .4$ & Construction \\
\hline
\end{tabular}

Aosta Valley were the most affected areas. Indeed, Piedmont produced and published a comprehensive impact assessment study (Regione Piemonte, 2000a, 2000b), and both regions provided flood extension maps produced through on-site assessments and aerial photo interpretation. In the remaining regions (i.e. Lombardy and Emilia-Romagna) ARPA Emilia Romagna and the Po River Basin Authority provided information about the flood extension based on on-site observations. In these regions the flood recorded a maximum extension of the water confined within the 200 years return period dykes along the Po river. Fig. 2 shows the area of study (Northern Italy) and the flood extension (in blue). These digital maps provide high resolution flood extension but no information on water depth.

\subsection{Direct economic impact assessment}

In recent years, an increasing number of studies have used land cover characteristics and water depth-damage functions for the assessment of the economic impacts of flood risk (Balica et al., 2013; Feyen et al., 2012; Kreibich et al., 2010; Rojas et al., 2013; Saint-Geours et al., 2014; Thieken et al., 2008), which is the most common methodology for the estimation of damage (Green et al., 2011; Jongman et al., 2012; Merz et al., 2010; Meyer and Messner, 2005). A depth-damage function provide the relationship between water depth and monetary damage for a specific land use type. The intersection of flood extension maps (with water depth sometimes complemented by other parameters such as velocity, 


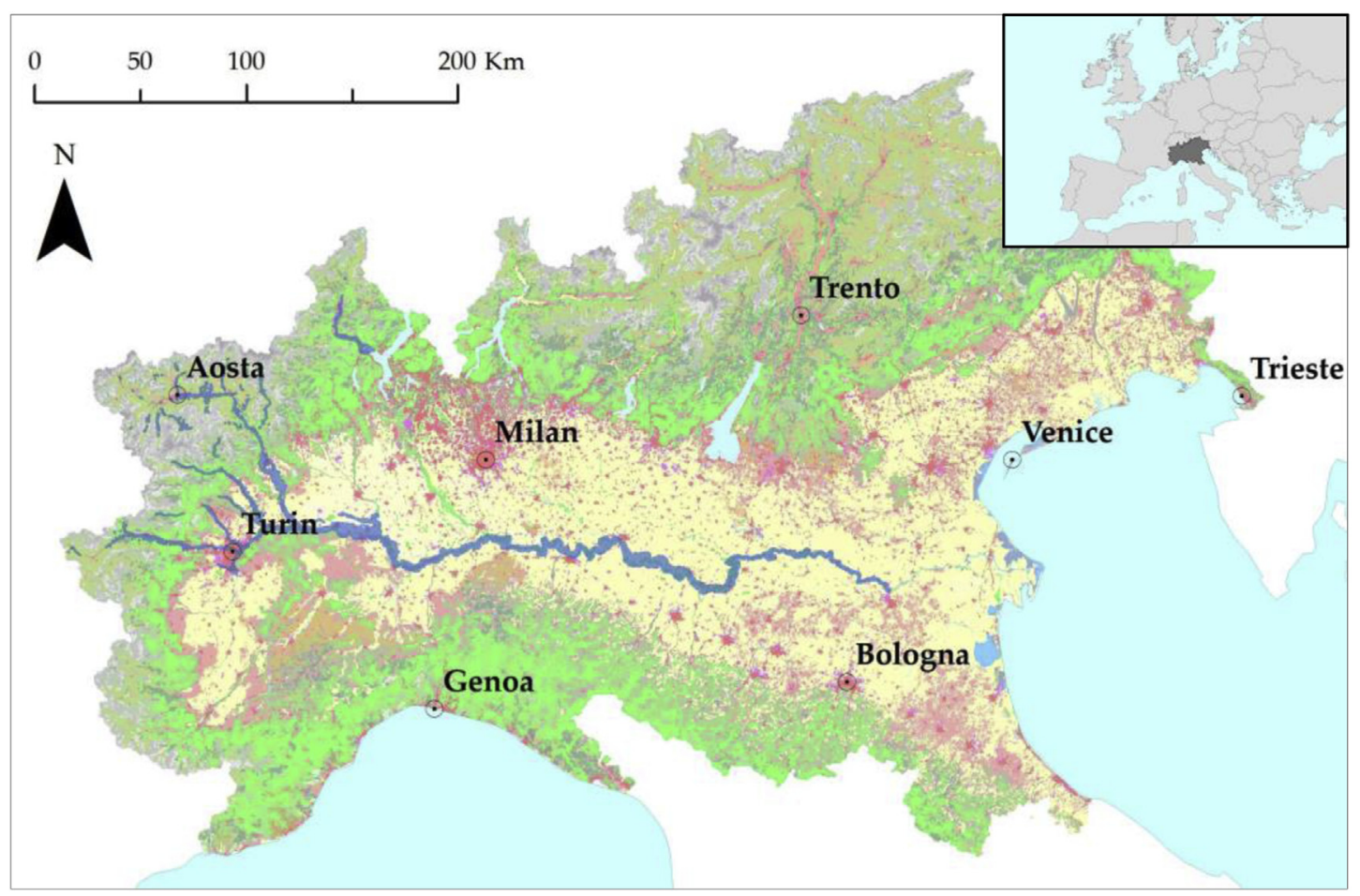

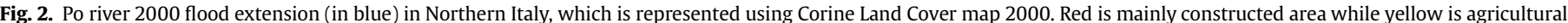

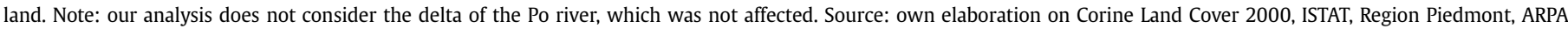

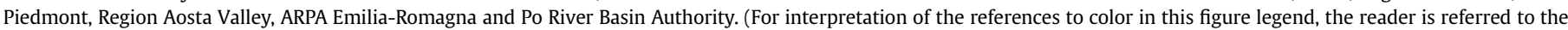
web version of this article.)

duration, etc.) with land use maps of the flooded area, enables the calculation of direct damages of a flood event (Merz et al., 2010; Meyer et al., 2013).

For consistency purposes in flood risk assessment amongst European River Basin Districts the European Commission's (EC) Joint Research Centre (JRC), Institute for Environment and Sustainability, developed a first Pan-European flood depth-damage function dataset for all EU27 Member States, including maximum damage values for each land use type (Huizinga, 2007). This dataset has been used in pan-European flood risk assessments (Feyen et al., 2012; Rojas et al., 2013). Flood depth-damage functions are affected by a large degree of uncertainty in curves construction and the value of the assets (De Moel and Aerts, 2011; Green et al., 2011; Jongman et al., 2012; Merz et al., 2010). Moreover they provide country-scale curves only, without consideration given to local or regional differences. However given the primary focus of our study on indirect impacts and the limitation of information available (digitally available flood extension maps did not reported water depth, which we did not computed for) we found JRC's damage functions particularly suitable for our purposes. As described in Huizinga (2007) these damage functions do not represent depreciated values but full replacement cost of the damaged asset or good. Hence this approach may overestimate the damage (Merz et al., 2010), because it does not capture the traditional definition of value of a capital good, which is the present value of income of flow it generates over the remaining of its life period (GeorgescuRoegen, 1993). However we believe that this method provides an acceptable estimation of the stock damaged by the flood event within the impacted area, i.e. the direct impact.

Our methodology proceeds as follows: we overlay CLC2000 map with the recorded flood extent, provided by the aggregation of the spatial layers available. The result is the flooded land, characterised by a specific use. Flooded areas are divided into five categories: urban continuous (CLC2000 code 1.1.1), urban discontinuous (1.1.2.), transport infrastructures $(1.2 .2,1.2 .3,1.2 .4$.), industry and commercial (1.2.1.), agriculture (2.all).

The direct economic impact is a function of the type of land use (damage value per each land use), the level of the damage (damage factor, based on water depth), and the extension of the flooded area by land use type.

$\mathrm{DEI}=\sum_{i=1}^{4} \mathrm{DV}_{i} \times \mathrm{DF}_{i} \times \mathrm{Ext}_{i}$

where $i=$ land use type: residential buildings (1), commercial and industrial (2), agriculture (3), transport infrastructure (4). DEI is the direct economic impact, DV is the damage value, DF is the damage factor, Ext is the extension of the flooded area.

Table 2 shows the maximum damage values for some EU Member States and the damage factor range of values (from a minimum of $1 \mathrm{~m}$ water depth to a maximum of $6 \mathrm{~m}$ and over). In Huizinga's functions (2007), the maximum damage values were elaborated from existing studies across some EU countries and the average damage value per land use class was applied to other EU Member State scaled to GDP per capita (Jongman et al, 2012). The functions were built on observations from nine countries. In countries without prior damage function data (such as Italy), the average functions were used per for each land use class (Huizinga, 2007). The damage functions and maximum damage values are nationally homogenous, they do not account for regional differences.

As already mentioned, water depth is not provided in the digital version of our flood maps. To cover a range of potential impacts, we consider two scenarios of average water depth, $1 \mathrm{~m}$ and $6 \mathrm{~m}$, the latter corresponding to the maximum damage value in Huizinga 
(2007). It is worth to highlight that in general, flood damage functions are characterised by large uncertainties in the maximum damage values, the depth damage curves as well as in the details of the damage categories (De Moel and Aerts, 2011; De Moel et al., 2012; Jongman et al., 2012; Merz and Thieken, 2009; SaintGeours et al., 2014). Therefore our direct impact assessment could potentially be not very accurate (and potentially overestimated). However it provides an order of magnitude of direct losses to compare with the outputs of the indirect impact assessment.

Based on the aggregation of land classes, the following assumptions are considered: (1) since CLC2000 does not distinguish between industry and commercial, the average of the two is applied (i.e. $475.5 \mathrm{Euro} / \mathrm{m}^{2}$ ); (2) because of their lower density, discontinuous urban area value is considered half of continuous (i.e. 309 Euro $\left./ \mathrm{m}^{2}\right)$; (3) in the plain area of the valley, roads are normally elevated from the average ground level. For this reason only a portion of road's damage value is considered for transport infrastructure surfaces $\left(14 \mathrm{Euro} / \mathrm{m}^{2}\right.$ ). The same value was also extended to airports and railways.

\subsection{Indirect economic impact assessment using the CGE model}

Indirect economic impacts are assessed through the use of a CGE model. The family of models have been increasingly applied by national and international institutions to a wide range of issues, such as tax reforms, trade liberalization, energy policy, and recently, the economic effects of climate change impacts (Standardi et al., 2014).

A CGE model is a system of equations which describes the behaviour of the economic agents (representative household and firm), the structure of the markets and the institutions, and the links between them. In the model mechanisms consumers maximize utility subject to an individual budget constrain. Firms maximize profit choosing the amount of inputs. Primary factors, such as land, capital, labour and natural resources, are owned by the household and are fixed in supply. The equilibrium in the market system is achieved when the demands of buyers match the supplies of sellers at prevailing prices in every market simultaneously. Global CGE trade models, such as the one used for our work, which is based on GTAP7 (Global Trade Analysis Project, reference year 2004) (Narayanan and Walmsley, 2008) have a Walrasian structures. Money is neutral, factors are fully employed, and the markets are perfectly competitive. In addition, macroeconomic closure is neoclassical as investments are driven by savings. Trade balance is determined endogenously. CGE model parameterization derives from a calibration procedure. That is, key behavioural parameters replicate the observed demand and supply relations in a given reference year. We followed the same procedure for the specification of sub-national relations in the CGE (see Appendix for the description of CES (Constant Elasticity of Substitution) and CET (Constant Elasticity of Transformation) functions).

As anticipated the time scale of our indirect impact analysis is one year and our CGE model is static. Each single 'shock' to the economic system (in our case to the productivity of primary factors of production such as capital, land, labour) translates into an impact on flows, i.e. a yearly disruption of regional/sectorial output and GDP. Within the year, we assume that the reduction in factors productivity is recovered within a selected timeframe depending on the economic sector (from 1 week of non-agriculture sectors to a maximum duration of 3 months for the agriculture sector). The uncertainty in production loss duration is dealt with considering three different duration scenarios based on authors' judgement and literature (Kajitani and Tatano, 2014; Pfurtscheller, 2014). We acknowledge the fact that more extensive sensitivity analysis could better represent this type of uncertainty. The shock is enforced to the one year point of the disaster occurrence and does not influence precedent or subsequent years. No subsidies and post-disaster reconstruction are accounted for in the economic model, aside from the indirect effects on the duration of the recovery period. Inventories are also not considered.

\subsubsection{The sub-national CGE model for Italy}

Most global CGE models are limited in terms of the scale of analysis. They normally use of national panel data, with no detail at the sub-national level, which can be particularly important to capture highly spatially-heterogeneous flood impacts (Hallegatte, 2012). Few CGE models report a sub-national detail at the same time keeping track of international relations. ${ }^{1}$ Building such a tool requires a not negligible effort both in the database construction and in the modelling of the theoretical structure. We start from the GTAP model (Hertel et al., 1997), which presents the country as the highest geographical detail.

In order to derive a consistent sub-national economic description we used three datasets: (1) the GTAP 7 database (Narayanan and Walmsley, 2008) which reports economic flows in the reference year 2004 for 57 sectors and 113 countries or groups of countries worldwide; (2) the sub-national dataset of ISTAT (Italian National Statistical Institute) from the same year, which provides information on value added, labour and land for the 20 Italian regions and 40 economic sectors; (3) ISTAT bilateral flows of carried goods (in tons) by mode of transportation (truck, rail, water and air) for the 20 Italian regions. We followed a three steps procedure: (a) we matched the 40 ISTAT sectors with the 10 GTAP sectors chosen in our aggregation and reported in Table 3. We distributed the Italian value added and primary factors in GTAP across the three Italian macro-regions (North, Centre and South) using the shares of ISTAT for value added, labour and land. Capital was computed as a difference between value added and labour. For the sectors that use natural resources we took the sub-national share of value added in those sector as a proxy; (b) we used the shares obtained from ISTAT transport data to split the sectorial GTAP Italian production between domestic sub-national demand and bilateral trade flows across Italian regions; (c) we adjusted the bilateral trade flows across Italian regions to make them consistent with the ISTAT data on the economic production by using the RAS statistical method (for more details see Standardi et al., 2014).

The modification of the model also requires some adjustments of the theoretical structure to incorporate the possibility of an increasing spatial mobility in both factors and goods market at the sub-country level, because both goods and factors usually move easier within the country than between countries (more details, including the main equations are described in the Appendix). In GTAP primary factors cannot move outside the country they belong to. This is partially justified in an international context, but it is not realistic within the same country, where for instance workers and capital can reallocate (at least partially) in other regions following push or pull economic factors. Moreover in a standard CGE model, the Armington assumption (Armington, 1969) applies. It postulates that homologous domestic and imported goods are not perfectly substitutable in consumer preferences. This prevents unrealistic specialization phenomena and trade overflows. The values of the Armington elasticity are set by econometric estimations, which are carried out at the national level. Within national borders, the Armington assumption, that needs to be kept in order to avoid unrealistic specialization and trade between regions, needs to be realistically weakened (McCallum, 1995). Armington elasticities

\footnotetext{
${ }^{1}$ For a survey of the literature on sub-national CGE models see section 2 in Perali et al. (2012) and Rodriguez and Primo (2007).
} 
were thus recalibrated at the sub-national level and the demand structure modified accounting for the higher product substitution inside than outside the Italian borders (for more details see Appendix and Standardi et al., 2014).

To account for the effects of these different assumptions we considered two recovery scenarios. The first scenario is represented by a rigid model that has the same theoretical structure and parameterization of GTAP. This means sub-national regions behave exactly like countries. As a result, factor endowments cannot move outside the sub-national region they belong and the trade in the sub-national region has the same Armington elasticity as in the standard GTAP model. The second model is a more flexible one. We introduced capital and labour mobility within Italy (endogenous factor supply at the sub-country level) through a CET function (see Appendix). As a result labour and capital can move across the Italian sub-national region after a shock in the economic system. We also modified the values of the Armington elasticity for the subnational regions to take into account the fact that products are closer substitutes within the country than across countries. ${ }^{2}$

The sectorial and geographical aggregations of the sub-national CGE model are shown in Tables 3 and 4.

\subsubsection{Measuring indirect impacts}

Table 5 provides an overview on the relation between the CGE sectors and the other datasets: land use (CLC2000), national and regional datasets on value added, land, labour, flows of transported goods (from ISTAT), and GTAP sectors.

We aggregate CLC2000 classes into four categories: agricultural, industrial/commercial, infrastructural, and urban. For the estimation of capital and land losses we associate the following land use class and economic sectors (Table 5): agriculture land is associated with grains and crops and livestock meat products; industrial/commercial land with processed food, textiles and clothing, light manufacturing and heavy manufacturing; infrastructure land with utilities and construction, which includes electricity, gas and water distribution; urban land with trade and communication and other services.

For the estimation of labour productivity losses we associate the six categories of workers defined by ISTAT (Italian National Statistics Institute) (agriculture, extraction, manufacture, construction, transport and services) to our CGE sectors (Table 5). We associate agriculture workers are associated with grains and crops and livestock meat products; extraction workers with mining and extraction; manufacture workers with processed food, textiles and clothing, light manufacturing and heavy manufacturing; construction workers with utilities and construction; transportation workers with trade and communication (in GTAP this sector includes also transport activities); services workers with other services.

Summarizing, we design the following inputs for the CGE model simulations:

a) As described in 3.2, we use the result of equation (1) as a proxy to quantify the land productivity loss in the sectors: grains and crops, and livestock meat products. We assume that the impact lasted for one, two, and three months ${ }^{3}$;

b) By the same token and following equation (2), we compute labour productivity losses in agriculture are computed for a period of one, two, and three months of interrupted activity;

\footnotetext{
${ }^{2}$ For further details about the calibration of the sub-national parameters refer to the Appendix.

${ }^{3}$ We are aware that these periods may not be accurate and need to be refined by additional studies. For our modelling purposes, this uncertainty was included considering three reasonable scenarios based on the specific characteristics of the livestock sector and seasonal farming (autumn-winter crops).
}

c) In all the other sector capital and labour follow equations (1) and (2), but assuming a shorter duration of impact: one, two, three weeks, as these sectors are less dependent upon land.

We compute the impact of the flood event for each sub-national region (North, Centre and South), Italy as a whole, the European Union (EU) and the rest of the world. Our outputs are: percentage change in real GDP and production in each sector. Absolute values have been computed using the Italian sub-national real GDP database (ISTAT) and scaled to Euro 2000 value using the World Development Indicator database (The World Bank).

\section{Results and discussion}

\subsection{Direct economic impacts}

Table 6 shows the flood affected areas by land use class.

We calculate the damage to the physical stock as in equation (3) using Huizinga (2007) damage functions (Table 7). We estimate the range of the damage for water depths of 1 and $6 \mathrm{~m}$ and above, which correspond to the minimum and the maximum damage factors in Huizinga (2007).

Our results show that the analysed flood event causes significant economic damages to all productive sectors and capital assets. We find that the largest share of losses occurs in the urban discontinuous and industrial/commercial areas, rather than in the urban continuous areas, as in other studies (Feyen et al., 2012; Rojas et al., 2013). We also register high level of losses in industrial/ commercial areas. This is probably due to the fact that our flood extension map is based on real post-event observations rather than simulation results obtained from hydrological models. The former captures the real-world heterogeneity of protection levels across different land uses. For instance urban centres in the Northern Italy may be effectively protected, while industrial activities are often located in flood risk areas (Regione Piemonte, 2000a, 2000b). Following the most conservative assumption our estimation calculates that the total damage amounts to almost 4 billion Euro in 2006 prices. Instead, with the highest damage factor, we estimate a total direct loss which exceeds 10,3 billion Euro (in 2006 prices).

\subsection{Indirect economic impacts}

Tables 8 and 9 describe the results of our spatial damage assessment feeding into the CGE model for indirect impact assessment.

The two tables are the input data of the CGE simulations. Six simulations are run in total, using three disruption duration scenarios on two post-disaster recovery scenarios (the rigid and the flexible model). Results are shown in Fig. 3. The North is the most affected area in both models, with the flexible one leading to higher losses. The flood has small to no impact on the Centre and the South

Table 6

Flooded areas by land use classes and the share of the total flood extent.

\begin{tabular}{llc}
\hline Description & Area $\left[\mathrm{km}^{2}\right]$ & \% Flood extent \\
\hline Agriculture land & 646.65 & 54.68 \\
Urban & 22.70 & 1.92 \\
$\quad$ Urban continuous & 0.61 & 0.05 \\
Urban discontinuous & 22.09 & 1.87 \\
Industrial-commercial & 5.71 & 0.48 \\
Infrastructure & 0.38 & 0.03 \\
Other classes & 507.19 & 42.89 \\
Total & 1182.66 & 100.00 \\
\hline
\end{tabular}


Table 7

Direct economic impacts (Euro 2006 prices). DF is damage factor. Source: own elaboration on CLC2000, flood extension maps and Huizinga (2007) damage functions.

\begin{tabular}{|c|c|c|c|c|c|c|}
\hline Description & Area $\left[\mathrm{km}^{2}\right]$ & Damage [Euro $/ \mathrm{m}^{2}$ ] & $\mathrm{DF}(1 \mathrm{~m})$ & $\mathrm{DF}(6 \mathrm{~m})$ & $\begin{array}{l}\text { Total damage }(1 \mathrm{~m}) \\
\text { [Mil Euro] }\end{array}$ & $\begin{array}{l}\text { Total damage }(6 \mathrm{~m}) \\
\text { [Mil Euro] }\end{array}$ \\
\hline Agriculture land & 646.65 & 0.63 & 0.55 & 1 & 224.0 & 407.4 \\
\hline Urban & 22.70 & & & & & \\
\hline Urban continuous & 0.61 & 618.00 & 0.40 & 1 & 151.8 & 379.6 \\
\hline Urban discontinuous & 22.09 & 309.00 & 0.40 & 1 & 2730.7 & 6826.8 \\
\hline Industrial-commercial & 5.71 & 475.50 & 0.30 & 1 & 815.3 & 2717.8 \\
\hline Infrastructure & 0.38 & 14.00 & 0.42 & 1 & 2.3 & 5.4 \\
\hline Other classes & 507.19 & 0.00 & - & - & 0 & 0 \\
\hline Total & 1182.66 & & & & 3924.3 & $10,337.1$ \\
\hline
\end{tabular}

Table 8

Land affected by the flood in the Northern Italy.

\begin{tabular}{llll}
\hline Description & $\begin{array}{l}\text { Total area } \\
{\left[\mathrm{km}^{2}\right]}\end{array}$ & $\begin{array}{l}\text { Flooded area } \\
{\left[\mathrm{km}^{2}\right]}\end{array}$ & $\begin{array}{l}\text { As \% of } \\
\text { Northern IT }\end{array}$ \\
\hline All & $119,521.15$ & 673.24 & 0.56 \\
Agriculture land & $54,214.89$ & 646.65 & 1.19 \\
Urban & 5451.89 & 22.7 & 0.41 \\
Industrial-commercial & 1196.13 & 5.71 & 0.48 \\
Infrastructure & 184.20 & 0.38 & 0.21 \\
\hline
\end{tabular}

in the rigid model due to the low market integration assumed (for this reason they are not reported in Fig. 3).

In the flexible specification the Northern consumer and firm can more easily shift their purchases toward the Centre and the South. The consequence is a redistribution of the GDP from the North to the South and the Centre, which experience positive economic effects. Interestingly, results for Italy as a whole are similar both in the rigid and the flexible model. On the one hand this points out a comfortable robustness in the aggregated results. Introducing regional specificities does not transform entirely the economic pattern of the Italian supply and demands systems nor their response to shocks. On the other hand, it highlights the importance of introducing the regional analysis to capture relevant distributional effects. As expected, given the scale of the initial shock and the size of the economies involved, the impacts on the EU and the rest of the world are negligible (see further on this (Merz et al., 2010)), though not reported.

It is worth noting that the Centre and the South do not compensate the GDP and production loss in the North in the flexible model. In this version of the model the loss of productivity in the North (given by the flood impact) induces two mechanisms: i) a relocation of capital and labour from the North to the Centre and the South, where the demand for primary factors is not negatively affected and returns are higher; ii) the increase of the demand in the North for goods produced in the Centre and the South, allowed by the greater product substitutability deriving from the increase of the Armington elasticities. The result is that losses increase in the North, whereas Centre and South gain. As already mentioned, the aggregated effect in Italy is negative and very similar to the rigid version of the model, but the geographical distribution is more uneven.
The model also offers disaggregated sectorial results (Fig. 4). In the North the most affected sectors are grains and crops, and livestock meat products, both in the rigid and flexible model. The same sectors in the Centre and the South increase their production both in the rigid and flexible model, with larger gains in the flexible model.

We estimate the indirect losses in the North to range from 644 million to 2537 million Euro (in 2000 values), depending on the type of the model (rigid-flexible) and the duration of the disruption (Fig. 5). Using the flexible model, due to the mobility factors a slightly positive effect is recorded in the Centre and the South. The indirect losses on Italy as a whole ranges from 647 to 1955 million Euro (in 2000 values).

\subsection{Discussion of results}

Indirect losses at country level represent a significant share of direct losses, which according to our estimation range from 3.3 to 8.8 billion Euro (in 2000 value). At country level both the rigid and the flexible models provide similar results of indirect losses. In the flexible model, the larger negative impact to the Northern economy is partially compensated by a positive effect in the other regions (Centre and South). It is a good signal that the flexible model is better designed to capture also positive effects of disasters, keeping constant the total indirect economic loss at country level.

Fig. 6 shows the range of the results in terms of absolute losses. Direct impacts depend on the assumptions made with respect to the flood water depth. Indirect impacts are influenced by the duration of the impact on the productivity. Monetary values are actualized to Euro 2000 values, assuming the economic system of 2000 being similar to the economic system in 2004 (the CGE model base year).

Because of the objective impossibility to work with a nondisaster counterfactual, the validation of our results is extremely difficult. Empirical evidence of changes in the regional and national economy and production are not available. We thus report some comparison with the literature conducting similar experiments. In our estimations, the ratio between indirect (at country level) and direct losses is around 0.19-0.22. Compared to the EM-DAT loss data for the same event (8.6 billion Euro) our indirect loss at country level ranges from 7 to 22 percent. The EMDAT dataset is

Table 9

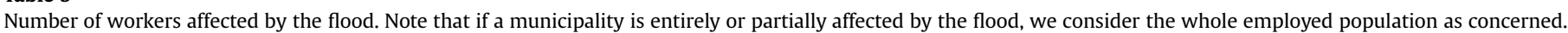

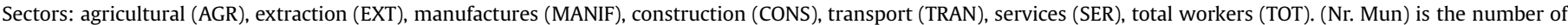
municipalities affected. Numbers in italics refer to the CGE sectors listed in Table 3. Source: own elaboration on ISTAT Census 2001.

\begin{tabular}{|c|c|c|c|c|c|c|c|c|}
\hline Description & Nr. Mun & AGR & EXT & MANIF & CONS & TRAN & SERV & TOT \\
\hline CGE sectors & & 1,2 & 3 & $4,5,6,7$ & 8 & 9 & 10 & \\
\hline North total & 4541 & 435,290 & 116,047 & $3,259,352$ & 867,645 & 497,706 & $5,817,653$ & $10,993,693$ \\
\hline North Flooded & 367 & 33,377 & 13,928 & 307,878 & 79,221 & 51,378 & 601,462 & $1,087,244$ \\
\hline North Flooded (\%) & 8 & 8 & 12 & 9 & 9 & 10 & 10 & 10 \\
\hline
\end{tabular}




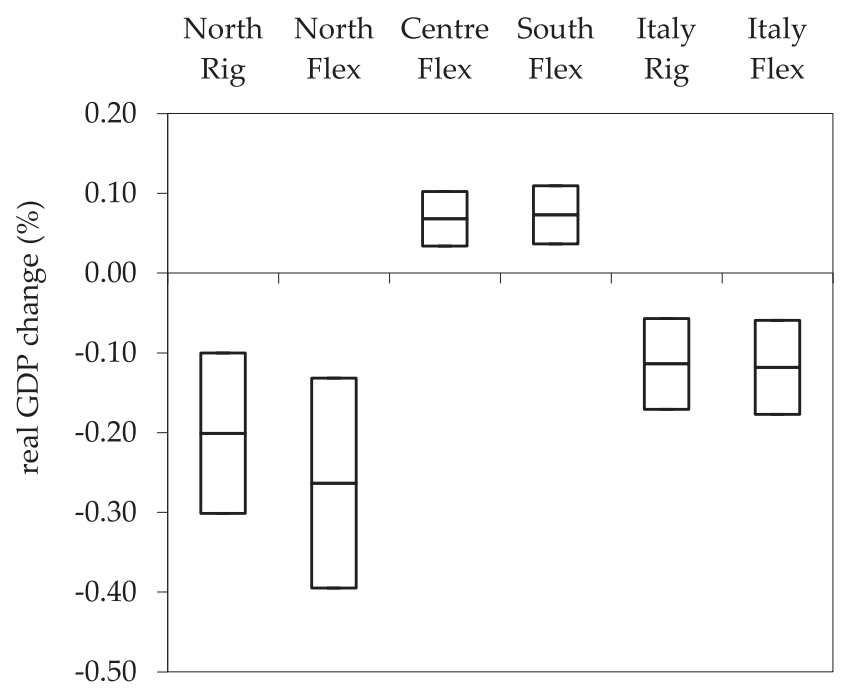

Fig. 3. Range of sub-national and national GDP variations (in percentage of real GDP) for different type of models: rigid $=$ rig, flexible $=$ flex, depending on the different duration of the impact. Centre and South Rig are not reported because the change is null.

reported to be a (not always transparent) combination of direct and indirect impacts. Other studies on indirect impact assessment of natural disasters provide figures in the same order of magnitude. For example, indirect economic losses in Louisiana after Katrina were estimated as 42 billion US\$ compared to 107 billion US\$ direct losses, that is 39 percent (Hallegatte, 2008). The assessment of the indirect losses caused by sea level rise and storm surge in Copenhagen associated to a potential direct loss of 9300 million Euro, provided an indirect loss of 747 million Euro, which is a ratio of 0.08 (Hallegatte et al., 2011). These studies also highlight a clear nonlinear increasing relation between indirect and direct losses (Przyluski and Hallegatte, 2011) which are also highly site- and hazard-specific. We acknowledge that additional research could corroborate our results, e.g. post-event econometric analysis to avoid noise and other perturbations existing in the annual production datasets (ISTAT).

\section{Conclusion and policy implications}

The economic analysis of natural hazard (notably flood) impacts focuses far too often on the direct damage to physical assets only,

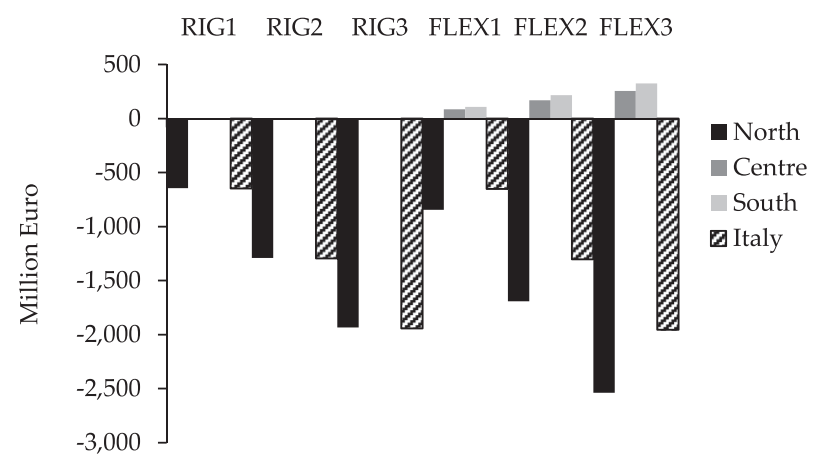

Fig. 5. Indirect economic impacts (2000 Euro value). Rig is the rigid model, while Flex is the flexible model. Numbers define the duration of the impact. (1) 1 months for agriculture and 1 week for other sectors; (2) 2 months for agriculture and 2 week for other sectors; (3) 3 months for agriculture and 3 weeks for other sectors. Economic losses are expresses in million Euro 2000 value. In the rigid model the impacts in the Centre and South are negligible, hence not reported.

neglecting the wider indirect losses set off by the former. The global disaster databases such as EM-DAT do little to disentangle the direct from the higher order losses. Hence, the full social cost of natural hazards remains poorly understood. In a world of growing interdependency of national economies, an improved acquaintance of indirect economic losses is an essential prerequisite for a full appreciation of hazard risk.

In this paper, we examined a combination of spatially explicit damage assessment with macroeconomic loss propagation using a regionally calibrated version of a global CGE model. We applied the model on example of the destructive Po river flood that occurred in October 2000 in Piedmont, Aosta Valley, and other downstream regions in the Northern Italy. Paying due attention to the uncertainty regarding the length of disruption and the aftermath recovery, we analysed three scenarios of productivity falloff and two scenarios of inter-sectorial recovery. The direct flood damage was estimated by spatially explicit flood depth-damage functions over aggregated land use classes. The result of the spatial analysis were used to 'shock' the regional economy in the Northern Italy by weakening the primary factors' productivity (capital, land and labour) that are exogenous parameters of the CGE model. To account for the regional effects of the revisited event, we disaggregated a global CGE model with a country resolution to sub-national units, i.e. groups of regions almost equivalent the NUTS1 level. We also

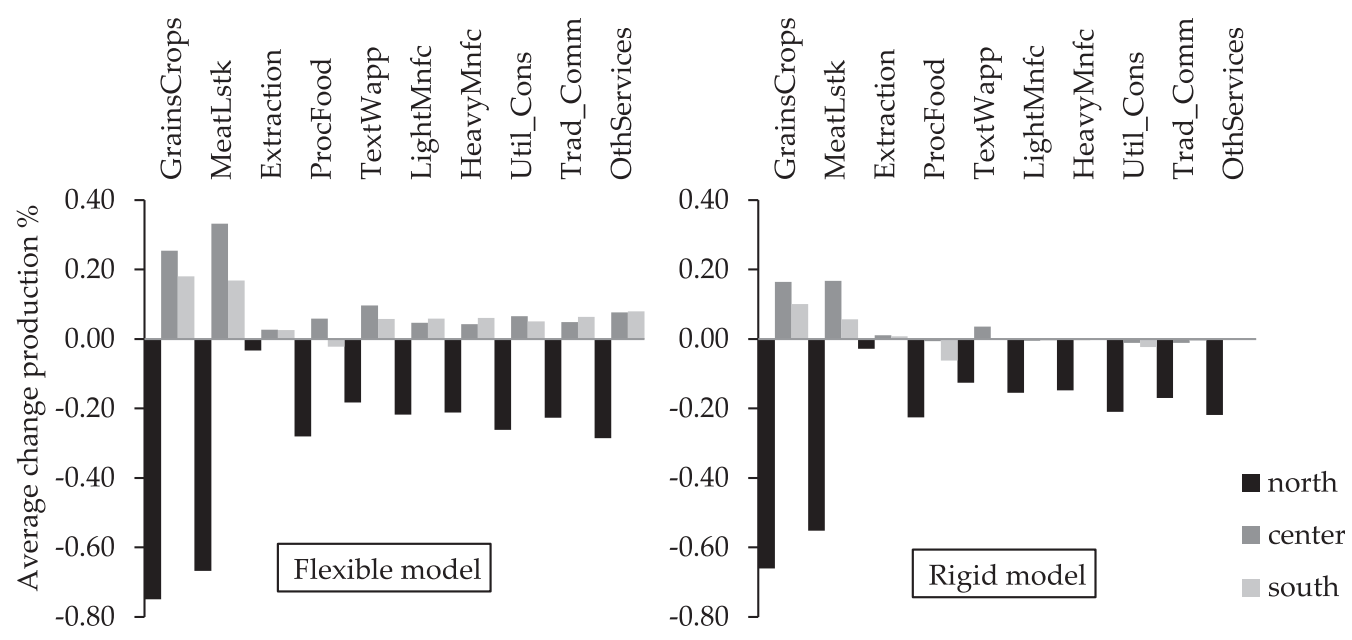

Fig. 4. Inter-sectorial distribution of the impacts: percentage of production variation in the North, Centre and South of Italy. 


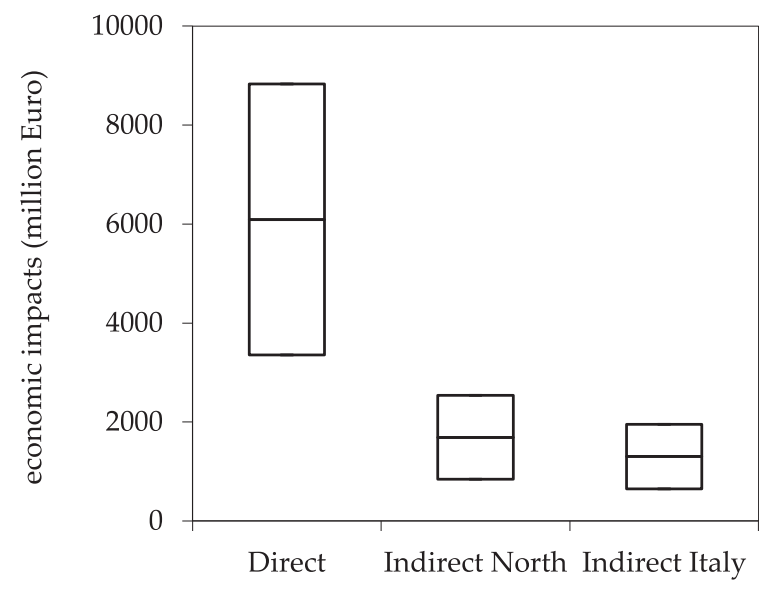

Fig. 6. Range of direct and indirect losses (in the North and Italy as a whole) using the flexible model. Values are given in million Euro 2000 value.

modified factors' mobility and substitutability of goods in consumers' preferences accordingly. The flood impacts were estimated in terms of the real GDP and the production changes for each economic sector in the North, Centre and South of Italy, Italy as a whole, the rest of Europe, and the rest of the world.

The results are considerable both in absolute and relative terms. We estimated direct impacts to range between 3.3 and 8.8 billion Euro (in 2000 values) depending on water depth assumptions. The indirect impacts were estimated as falling between 0.64 and 1.95 billion Euro (in 2000 values), depending on the controlled flexibility of substitution and mobility (rigid-flexible) and the length of productivity falloff. The approximated indirect losses amount to around one fifth (19-22 percent) of the direct losses, depending on the assumptions made. Considering the limitation of existing empirical information on 2000 Piedmont flood, our estimations match remarkably the results of other studies. The regionally disaggregated CGE model is instrumental to tracing down the transfer of disaster's effects across regions. The flexible version of the model is able to unravel the impact of a disaster into differentiated effects in sub-national economies, positive or negative as they may be depending on the location of the event.

Our analysis suggests that indirect losses play an important role in the full social costs of floods. The methodology detailed in this paper is applicable to other natural hazards (e.g. storm surges, forest fires, earthquakes, volcanic eruptions, avalanches, etc.) and/ or countries and regions. Although data intensive and time consuming, the construction of a Pan-European CGE model disaggregated to NUTS2 level would make the indirect assessment more precise and sensitive to the regional differences of the hardship suffered. As a result, the EU disaster risk reduction policies would be better informed by empirical evidence, as highlighted in the EC (EC, 2009), EEA (EEA, 2013) and De Groeve (De Groeve et al., 2013). The policies benefiting from a more comprehensive risk analysis include the EU Flood Directive (2007/60/EC), the EU Solidarity and Structural Funds (De Groeve et al., 2013), and the Climate Change Adaptation (EC, 2013).

\section{Acknowledgements}

The research underlying this paper has received funding from the Italian Ministry of Education, University and Research and the Ministry for Environment, Land and Sea (the GEMINA project) and the EU's Seventh Framework Programme (FP7/2007-2013) under grant agreement $n^{\circ} 265213$ (EPI-WATER - Evaluating Economic Policy Instruments for Sustainable Water Management in Europe).
The four authors designed jointly the research exercise. L.C. and G.S. performed the empirical analysis to which F.B. and J.M. contributed with expert judgement and guidance. The authors are grateful to Fabio Eboli for supervising the CGE analysis and valuable advices, and the four anonymous reviewers for appreciated comments and suggestions which without doubts led to sizeable improvements of the paper.

\section{Appendix. The Italian sub-national CGE model}

\section{Supply}

The value added in the standard GTAP model originates from five primary factors: land, natural resources, unskilled labour, skilled labour and capital. All the sectors use labour and capital while only some use land and natural resources (agriculture and mining-related sectors, respectively). Land and natural resources supply is sluggish across sectors while labour and capital are perfectly mobile. All the primary factors are spatially immobile. For our sub-national context, we assume the following:

1) Primary factors sectorial mobility does not change.

2) Land and natural resources remain spatially immobile at the sub-national level.

3) Sub-national unskilled labour, skilled labour and capital supply is geographically sluggish within Italy and still immobile with respect to the rest of Europe and the rest of the world.

The third assumption is new with respect to the standard GTAP model. It is implemented through a CET (Constant Elasticity of Transformation) function: as a result, workers and capital can move outside the Italian region they belong to in response to economic shocks.

First order conditions of the CET supply function and the formula to determine the national price of the endowment (shadow price) are given in the equations $1-6$, where $\mathrm{QL}, \mathrm{QH}, \mathrm{QK}, \mathrm{PL}, \mathrm{PH}$, and PK represent, respectively, the quantity of supplied unskilled labour, skilled labour, capital and the associated prices in the subnational region. ITA and $r$ are, respectively, the unique Italian aggregate index and the sub-national index. The parameters $\sigma_{\mathrm{L}}, \sigma_{\mathrm{H}}$ and $\sigma_{\mathrm{K}}$ are the elasticity of substitution of the endowment supply, they are a measure of geographical mobility. Increasing the absolute value of these parameters means increasing the factors mobility within Italy. At this stage, we make the hypothesis that $\sigma_{\mathrm{L}}=\sigma_{\mathrm{H}}=\sigma_{\mathrm{K}}$.

$$
\begin{aligned}
& \mathrm{QL}_{\mathrm{r}}=\mathrm{QL}_{\mathrm{ITA}}\left(\frac{\mathrm{PL}_{\mathrm{ITA}}}{\mathrm{PL}_{\mathrm{r}}}\right)^{\sigma_{\mathrm{L}}} \text { with } \sigma_{\mathrm{L}}<0 \\
& \sum_{\mathrm{r}} \mathrm{QL}_{\mathrm{r}} \mathrm{PL}_{\mathrm{r}}=\mathrm{QL}_{\mathrm{ITA}} \mathrm{PL}_{\mathrm{ITA}} \\
& \mathrm{QH}_{\mathrm{r}}=\mathrm{QH}_{\mathrm{ITA}}\left(\frac{\mathrm{PH}_{\mathrm{ITA}}}{\mathrm{PH}_{\mathrm{r}}}\right)^{\sigma_{\mathrm{H}}} \text { with } \sigma_{\mathrm{H}}<0 \\
& \sum_{\mathrm{r}} \mathrm{QH}_{\mathrm{r}} \mathrm{PH}_{\mathrm{r}}=\mathrm{QH}_{\mathrm{ITA}} \mathrm{PH}_{\mathrm{ITA}} \\
& \mathrm{QK}_{\mathrm{r}}=\mathrm{QK}_{\mathrm{ITA}}\left(\frac{\mathrm{PK}_{\mathrm{ITA}}}{\mathrm{PK}_{\mathrm{r}}}\right)^{\sigma_{\mathrm{K}}} \text { with } \sigma_{\mathrm{K}}<0 \\
& \sum_{\mathrm{r}} \mathrm{QK}_{\mathrm{r}} \mathrm{PK}_{\mathrm{r}}=\mathrm{QK}_{\mathrm{ITA}} \mathrm{PK}_{\mathrm{ITA}}
\end{aligned}
$$


The value of $\sigma_{K}, \sigma_{\mathrm{L}}$ and $\sigma_{\mathrm{H}}$ ranges from 0 to -1 . No doubt arises for the case of perfect factor immobility $\left(\sigma_{K}=\sigma_{L}=\sigma_{H}\right)$ as the value immediately derives from the economic theory. In the case of imperfect factor mobility we base our guess on the sensitivity analysis carried out in Standardi et al. (2014), which has shown as results are more sensitive for values included between 0 and -5 . For this reason and given the fact that we are not considering long run effects but only effects which take place within a year, the value is set to be equal to -1 . This is to avoid unrealistic changes in the labour and capital supply. However we are aware that an econometric estimation would be worthy to get more robust guess.

\section{Demand}

In the standard GTAP model the demand side is composed by private consumption, government spending and intermediate goods. The demand tree follows a double nest. The first nest links domestic demand and aggregate foreign imports of a specific commodity (irrespective of origin country) for each agent (households, government, firms). The second nest differentiates foreign imports according to the geographical origin. The second model improvement thus consists in modifying the demand tree in order to make sub-national products closer substitutes among them than the foreign products.

To achieve this goal we insert four additional parameters $\sigma_{\mathrm{ARM}}$, $\sigma_{\text {IMP1 }}, \sigma_{\text {ARM2 }}$ and $\sigma_{\text {IMP2}}$. The parameters $\sigma_{\text {ARM }}$ and $\sigma_{\text {IMP }}$ are the Armington elasticities in the standard GTAP model representing in the country or group of countries the substitution between the national product and the aggregate foreign product and the substitution across foreign products which have different geographical origin; $\sigma_{\mathrm{ARM} 1}$ and $\sigma_{\mathrm{IMP} 1}$ are the Armington elasticities representing in the sub-national region the substitution between the national product and the aggregate foreign product and the substitution across foreign products which have different geographical origin; $\sigma_{\mathrm{ARM} 2}$ and $\sigma_{\text {IMP2 }}$ are the Armington elasticities representing in the sub-national region the substitution between the sub-national product and the aggregate product coming from the other subnational regions and the substitution across products coming from the other sub-national regions.

We use CES (constant elasticity of substitution) functions to model the inter-national and intra-national demands. As the following equations apply to all sectors in the same manner, for sake of algebraic simplicity we do not consider a sector index in the rest of this appendix.

Q QD and QM, represent, respectively, the quantity of total, domestic and imported good demanded by households, government or firms in the country or group of countries, represented by index c. QU, QDU and QMU are, respectively, total, national and international imported good by households, government or firms in the sub-national region $r$ (the suffix $U$ stands for upper level). QDL and QML represent the domestic and intra-national imported good in the sub-national region (the suffix $\mathrm{L}$ stands for lower level). P, PCD, PM, PU, PDU, PMU, PDL and PML are the associated prices.

The equations (7) and (8) show the mathematics behind the standard GTAP trade structure (still valid for rest of Europe and rest of the world in our model), the equations (9)-(12) describe the new structure for the sub-national regions (North, Centre and South of Italy):

$\mathrm{QD}_{\mathrm{c}}=\mathrm{Q}_{\mathrm{c}}\left(\frac{\mathrm{P}_{\mathrm{c}}}{\mathrm{PD}_{\mathrm{c}}}\right)^{\sigma_{\mathrm{ARM}}}$ with $\sigma_{\mathrm{ARM}}>0$

$\mathrm{QM}_{\mathrm{c}}=\mathrm{Q}_{\mathrm{c}}\left(\frac{\mathrm{P}_{\mathrm{c}}}{\mathrm{PM}_{\mathrm{c}}}\right)^{\sigma_{\mathrm{ARM}}}$ with $\sigma_{\mathrm{ARM}}>0$
$\mathrm{QDU}_{\mathrm{r}}=\mathrm{QU}_{\mathrm{r}}\left(\frac{\mathrm{PU}_{\mathrm{r}}}{\mathrm{PDU}_{\mathrm{r}}}\right)^{\sigma_{\mathrm{ARM} 1}}$ with $\sigma_{\mathrm{ARM} 1}>0$

$\mathrm{QMU}_{\mathrm{r}}=\mathrm{QU}_{\mathrm{r}}\left(\frac{\mathrm{PU}_{\mathrm{r}}}{\mathrm{PMU}_{\mathrm{r}}}\right)^{\sigma_{\mathrm{ARM} 1}}$ with $\sigma_{\mathrm{ARM} 1}>0$

$\mathrm{QDL}_{\mathrm{r}}=\mathrm{QDU}_{\mathrm{r}}\left(\frac{\mathrm{PDU}_{\mathrm{r}}}{\mathrm{PDL}_{\mathrm{r}}}\right)^{\sigma_{\mathrm{ARM} 2}}$ with $\sigma_{\mathrm{ARM} 2}>0$

$\mathrm{QML}_{\mathrm{r}}=\mathrm{QDU}_{\mathrm{r}}\left(\frac{\mathrm{PDU}_{\mathrm{r}}}{\mathrm{PML}_{\mathrm{r}}}\right)^{\sigma_{\mathrm{ARM} 2}}$ with $\sigma_{\mathrm{ARM} 2}>0$

The value of $\sigma_{\mathrm{ARM}}$ and $\sigma_{\mathrm{IMP}}$ stems from GTAP, which, in turn, derive them by econometric estimation (Hertel et al., 1997).

In the rigid model two relations characterise the four parameters:

$\sigma_{\mathrm{ARM}}=\sigma_{\mathrm{ARM} 1}=\sigma_{\mathrm{ARM} 2}$

$\sigma_{\mathrm{IMP}}=\sigma_{\mathrm{IMP} 1}=\sigma_{\mathrm{IMP2}}$

In the flexible model the relations are following:

$\sigma_{\mathrm{ARM}}=\sigma_{\mathrm{ARM} 1}=2 / 3 * \sigma_{\mathrm{ARM} 2}$

$\sigma_{\mathrm{IMP}}=\sigma_{\mathrm{IMP} 1}=2 / 3 * \sigma_{\mathrm{IMP} 2}$

These relations take into account the increased product substitutability at the sub-national level. The factor $2 / 3$ is somewhat arbitrary. However for values smaller than $2 / 3$ the algorithm has troubles to converge to the optimal solution. As a consequence we can interpret it as a threshold to model substitution across subnational goods.

As in the case of factor market, econometric estimation would be more appropriate to assess the new Armington elasticities. Unfortunately, to the best of our knowledge they are not available for this kind of problem and we are forced to do some simplification.

\section{References}

Albala-Bertrand, J.M., 1993. Natural disaster situations and growth: a macroeconomic model for sudden disaster impacts. World Dev. 21, 1417-1434. http:// dx.doi.org/10.1016/0305-750X(93)90122-P.

Armington, P.S., 1969. A theory of demand for products distinguished by place of production. Staff Pap. Monet. Fund. 159-178.

Balica, S.F., Popescu, I., Beevers, L., Wright, N.G., 2013. Parametric and physically based modelling techniques for flood risk and vulnerability assessment: a comparison. Environ. Model. Softw. 41, 84-92. http://dx.doi.org/10.1016/ j.envsoft.2012.11.002.

Berrittella, M., Hoekstra, A.Y., Rehdanz, K., Roson, R., Tol, R.S.J., 2007. The economic impact of restricted water supply: a computable general equilibrium analysis. Water Res. 41, 1799-1813. http://dx.doi.org/10.1016/j.watres.2007.01.010.

Bosello, F., Nicholls, R.J., Richards, J., Roson, R., Tol, R.S.J., 2012. Economic impacts of climate change in Europe: sea-level rise. Clim. Change 112, 63-81.

Bosello, F., Roson, R., Tol, R.S.J., 2006. Economy-wide estimates of the implications of climate change: human health. Ecol. Econ. 58, 579-591.

Cavallo, E., Bank, I.D., Galiani, S., Pantano, J., 2012. Catastrophic Natural Disasters and Economic Growth (No. 183) (IDB Working Papers. Washington DC, USA).

Centre for Research on the Epidemiology of Disasters - CRED, n.d. EM-DAT The international disaster database [WWW Document]. URL www.emdat.be.

Chapter 3 Cochrane, H.C., 2004. Indirect Losses From Natural Disasters: Measurement And Myth. In: Okuyama, Yasuhide, Chang, Stephanie E. (Eds.), Modeling the Spatial and Economic Effects of Disasters. Springer, New York, NY.

De Groeve, T., Poljansek, K., Ehlrich, D., 2013. Recording Disaster Losses Recommendations for a European Approach. http://dx.doi.org/10.2788/98653. Ispra, Italy.

De Moel, H., Aerts, J.C.J.H., 2011. Effect of uncertainty in land use, damage models and inundation depth on flood risk estimates. Nat. Hazards 58, 407-425.

De Moel, H., Asselman, N.E.M., Aerts, J., 2012. Uncertainty and sensitivity analysis of coastal flood damage estimates in the west of the Netherlands. Nat. Hazards Earth Syst. Sci. 12, 1045-1058. 
EC, 2009. A Community Approach on the Prevention of Natural and Man-made Disasters. $\operatorname{COM}(2009) 82$ final. Brussels.

EC, 2013. An EU Strategy on Adaptation to Climate Change. COM (2013) 216. Brussels.

EEA, 2010. Mapping the Impacts of Natural Hazards and Technological Accidents in Europe an Overview of the Last Decade. European Environmental Agency, Copenhagen. http://dx.doi.org/10.2800/62638.

EEA, 2012. Climate Change, Impacts and Vulnerability in Europe 2012. European Environmental Agency, Copenhagen. http://dx.doi.org/10.2800/66071.

EEA, 2013. Towards a Potential European Flood Impact Database. European Environmental Agency, Copenhagen.

Farinosi, F., Carrera, L., Maziotis, A., Mysiak, J., Eboli, F., Standardi, G., 2012. Policyrelevant Assessment Method of Socio-economic Impacts of Floods: an Italian Case Study. FEEM Working Paper (No. 87-2012), FEEM Working Paper. Venice.

Feyen, L., Dankers, R., Bódis, K., Salamon, P., Barredo, J., 2012. Fluvial flood risk in Europe in present and future climates. Clim. Change 112, 47-62. http:// dx.doi.org/10.1007/s10584-011-0339-7.

Georgescu-Roegen, N., 1993. The Entropy Law and the Economic Problem. Valuing Earth Econ. Ecol. Ethics. MIT Press, Cambridge/Massachusetts, pp. 75-88.

Green, C., Viavattene, C., Thompson, P., 2011. Guidance for Assessing Flood Losses. CONHAZ report, pp. 1-86.

Guzzetti, F., Tonelli, G., 2004. Information system on hydrological and geomorphological catastrophes in Italy (SICI): a tool for managing landslide and flood hazards. Nat. Hazards Earth Syst. Sci. 213-232.

Haddad, E.A., Teixeira, E., 2013. Economic Impacts of Natural Disasters in Megacities: the Case of Floods in São Paulo. Brazil (No. 04-2013). TD Nereus, São Paulo.

Hallegatte, S., 2008. An adaptive regional input-output model and its application to the assessment of the economic cost of Katrina. Risk Anal. 28, 779-799. http:// dx.doi.org/10.1111/j.1539-6924.2008.01046.x.

Hallegatte, S., 2012. Modeling the Roles of Heterogeneity, Substitution, and Inventories in the Assessment of Natural Disaster Economic Costs (No. 6047) (Policy research working paper. Washington DC).

Hallegatte, S., 2014. An Exploration of the Link Between Development, Economic Growth, and Natural Risk (No. 6216) (Policy Research working paper. Washington DC).

Hallegatte, S., Ranger, N., Mestre, O., Dumas, P., Corfee-Morlot, J., Herweijer, C., Wood, R.M., 2011. Assessing climate change impacts, sea level rise and storm surge risk in port cities: a case study on Copenhagen. Clim. Change 104, 113-137.

Henriet, F., Hallegatte, S., Tabourier, L., 2012. Firm-network characteristics and economic robustness to natural disasters. J. Econ. Dyn. Control 36, 150-167. http://dx.doi.org/10.1016/j.jedc.2011.10.001.

Hertel, T.W., Tsigas, M.E., Hertel, T.W., 1997. Structure of GTAP. Glob. Trade Anal. Model. Appl. 13-73.

Huizinga, H.J., 2007. Flood Damage Functions for EU Member States - HKV Consultants, Implemented in the Framework of Contract \#382442-F1SC Awarded by the European Commission - Joint Research Centre.

IPCC, 2012. Managing the Risks of Extreme Events and Disasters to Advance Climate Change Adaptation. Cambridge University Press, Cambridge. http://dx.doi.org/ 10.1017/CBO9781139177245.

IRPI, n.d. Sistema Informativo Sulle Catastrofi Idrogeologiche [WWW Document]. URL http://sici.irpi.cnr.it/

Jongman, B., Kreibich, H., Apel, H., Barredo, J.I., Bates, P.D., Feyen, L., Gericke, a., Neal, J., Aerts, J.C.J.H., Ward, P.J., 2012. Comparative flood damage model assessment: towards a European approach. Nat. Hazards Earth Syst. Sci. 12, 3733-3752. http://dx.doi.org/10.5194/nhess-12-3733-2012.

Jonkhoff, W., 2009. Flood risk assessment and policy in the Netherlands. In: OECD (Ed.), Green Cities: New Approaches to Confronting Climate Change. OECD, Las Palmas de Gran Canaria, pp. 220-240.

Jonkman, S.N., Kelman, I., 2005. An analysis of the causes and circumstances of flood disaster deaths. Disasters 29, 75-97.

Kajitani, Y., Tatano, H., 2014. Estimation of production capacity loss rate after the Great East Japan earthquake and tsunami in 2011. Econ. Syst. Res. 26 (1), 13-38. http://dx.doi.org/10.1080/09535314.2013.872081.

Kreibich, H., Seifert, I., Merz, B., Thieken, A.H., 2010. Development of FLEMOcs-a new model for the estimation of flood losses in the commercial sector. Hydrol. Sci. J. -J. Des. Sci. Hydrol. 55, 1302-1314.

Kroll, C.A., Landis, J.D., Shen, Q., Stryker, S., 1991. Economic Impacts of the Loma Prieta Earthquake: a Focus on Small Businesses.

Kunreuther, H.C., Michel-kerjan, E.O., 2007. Climate Change, Insurability of Largescale Disasters and the Emerging Liability Challenge. In: NBER Working Paper Series (Cambridge MA).

Liang, Q.-M., Yao, Y.-F., Zhao, L.-T., Wang, C., Yang, R.-G., Wei, Y.-M., 2014. Platform for China Energy \& Environmental Policy Analysis: a general design and its application. Environ. Model. Softw. 51, 195-206.

McCallum, R.A., 1995. Instance-based utile distinctions for reinforcement learning with hidden state. In: ICML, pp. 387-395.

Merz, B., Kreibich, H., Schwarze, R., Thieken, A., 2010. Review article “Assessment of economic flood damage”. Nat. Hazards Earth Syst. Sci. 10, 1697-1724. http:// dx.doi.org/10.5194/nhess-10-1697-2010.

Merz, B., Thieken, A.H., 2009. Flood risk curves and uncertainty bounds. Nat. Hazards $51,437-458$.
Messner, F., Penning-Rowsell, E., Green, C., Meyer, V., Tunstall, S., van der Veen, A., 2007. Evaluating Flood Damages: Guidance and Recommendations on Principles and Methods. FLOODsite-Report T09-06-01.

Meyer, V., Becker, N., Markantonis, V., Schwarze, R., van den Bergh, J.C.J.M., Bouwer, L.M., Bubeck, P., Ciavola, P., Genovese, E., Green, C., Hallegatte, S., Kreibich, H., Lequeux, Q., Logar, I., Papyrakis, E., Pfurtscheller, C., Poussin, J., Przyluski, V., Thieken, a. H., Viavattene, C., 2013. Review article: assessing the costs of natural hazards - state of the art and knowledge gaps. Nat. Hazards Earth Syst. Sci. 13, 1351-1373. http://dx.doi.org/10.5194/nhess-13-1351-2013.

Meyer, V., Messner, F., 2005. National Flood Damage Evaluation Methods. A Review of Applied Methods in England, the Netherlands, the Czech Republic and Germany (UFZ Discussion Papers, UFZ-Discussion Papers. Leipzig).

Moffatt, I., Hanley, N., 2001. Modelling sustainable development: systems dynamic and input-ouput approaches. Environ. Model. Softw. 16, 545-557.

Molinari, D., Menoni, S., Aronica, G.T., Ballio, F., Berni, N., Pandolfo, C., Stelluti, M., Minucci, G., 2014. Ex post damage assessment: an Italian experience. Nat. Hazards Earth Syst. Sci. 14, 901-916. http://dx.doi.org/10.5194/nhess-14-9012014.

MunichRE, 2010. NatCatSERVICE [WWW Document]. URL. www.munichre.com.

Narayanan, G.B., Walmsley, T., 2008. The GTAP 7 Data Base. Cent. Glob. Trade.

Noy, I., Nualsri, A., 2007. What Do Exogenous Shocks Tell Us About Growth Theories? Santa Cruz Inst. for International Economics, Santa Cruz.

Okuyama, Y., 2007. Economic modeling for disaster impact analysis: past, present, and future. Econ. Syst. Res. 19, 115-124.

Okuyama, Y., 2014. Disaster and economic structural change: case study on the 1995 Kobe earthquake. Econ. Syst. Res. 37-41. http://dx.doi.org/10.1080/ 09535314.2013.871506.

Okuyama, Y., Hewings, G.D., Sonis, M., 2004. Measuring economic impacts of Disasters: interregional input-output analysis using sequential inter industry model. In: Okuyama, Y., Chang, S. (Eds.), Modeling Spatial and Economic Impacts of Disasters SE - 5, Advances in Spatial Science. Springer, Berlin Heidelberg, pp. 77-101. http://dx.doi.org/10.1007/978-3-540-24787-6_5.

Pauw, K., J, T., Bachu, M., Van Seventer, D.E., 2011. The economic costs of extreme weather events: a hydro-meteorological CGE analysis for Malawi. Environ. Dev. Econ. 16 (2), 177-198.

Perali, F., Pieroni, L., Standardi, G., 2012. World tariff liberalization in agriculture: an assessment using a global CGE trade model for EU15 regions. J. Policy Model. 34, $155-180$.

Pfurtscheller, C., 2014. Regional economic impacts of natural hazards - the case of the 2005 Alpine flood event in Tyrol (Austria). Nat. Hazards Earth Syst. Sci. 359-378. http://dx.doi.org/10.5194/nhess-14-359-2014.

Przyluski, V., Hallegatte, S., 2011. Indirect Costs of Natural Hazards (CONHAZ Report).

Ranger, N., Hallegatte, S., Bhattacharya, S., Bachu, M., Priya, S., Dhore, K., CorfeeMorlot, J., 2011. An assessment of the potential impact of climate change on flood risk in Mumbai. Clim. Change 104.1, 139-167.

Ratto, S., Bonetto, F., Comoglio, F., 2003. The October 2000 flooding in Valle d'Aosta (Italy): event description and land planning measures for the risk mitigation. Int. J. River Basin Manag. 1, 105-116.

Regione Piemonte, 2000a. Rapporto Sull'evento Alluvionale del 13-16 Ottobre 2000 Parte I (Turin).

Regione Piemonte, 2000b. Rapporto Sull'evento Alluvionale del 13-16 Ottobre 2000 Parte II (Turin).

Rodriguez, U., Primo, E., 2007. State-of-the-Art in regional computable general equilibrium modelling with a case study of the Philippines. Agric. Econ. Researh Rev. 20, 1-28.

Rojas, R., Feyen, L., Watkiss, P., 2013. Climate change and river floods in the European Union: socio-economic consequences and the costs and benefits of adaptation. Glob. Environ. Chang. http://dx.doi.org/10.1016/j.gloenvcha.2013.08.006 press.

Rose, A., 2004. Economic principles, issues and research priorities in hazard loss estimation. In: Okuyama, Y., Chang, S.E. (Eds.), Modeling the Spatial and Economic Effects of Disasters. Springer, New York.

Rose, A., Benavides, J., Chang, S.E., Szczesniak, P., Lim, D., 1997. The regional economic impact of an earthquake: direct and indirect effects of electricity lifeline disruptions. J. Reg. Sci. 37, 437-458. http://dx.doi.org/10.1111/00224146.00063 .

Rose, A., Liao, S.-Y., 2005. Modeling regional economic resilience to disasters: a computable general equilibrium analysis of water service disruptions. J. Reg. Sci. 45, 75-112. http://dx.doi.org/10.1111/j.0022-4146.2005.00365.x.

Saint-Geours, N., Bailly, J.-S., Grelot, F., Lavergne, C., 2014. Multi-scale spatial sensitivity analysis of a model for economic appraisal of flood risk management policies. Environ. Model. Softw. 60,153-166. http://dx.doi.org/10.1016/j.envsoft. 2014.06.012.

Standardi, G., Bosello, F., Eboli, F., 2014. A sub-national version of the GTAP model for Italy. Work. Pap Fond. Eni Enrico Mattei 2014.04, 1-20.

Strobl, E., 2010. The economic growth impact of Hurricanes: evidence from U.S. Coastal Counties. Rev. Econ. Stat. 93, 575-589. http://dx.doi.org/10.1162/REST_ a_00082.

The World Bank, n.d. World Development indicators [WWW Document]. URL http://data.worldbank.org/

Thieken, A.H., Olschewski, A., Kreibich, H., Kobsch, S., Merz, B., Proverbs, D., Brebbia, C.A., Penning-Roswell, E., 2008. Development and evaluation of FLEMOps-a new flood loss estimation model for the private sector. In: 1st 
International Conference on Flood Recovery, Innovation and Response (FRIAR), London, UK, 2-3 July 2008. WIT Press, pp. 315-324.

Tropeano, D., Turconi, L., 2001. Alluviuone del 14-16 Ottobre 2000 Nell'italia Nordovest: Cronaca di Sintesi e Commenti. NIMBUS.

Tsuchiya, S., Tatano, H., Okada, N., 2007. Economic loss assessment due to railroad and highway disruptions. Econ. Syst. Res. 19.2, 147-162.
United Nations International Strategy for Disaster Reduction Secretariat, 2009 Global Assessment Report on Disaster Risk Reduction. Geneva. doi: 9789211320282.

Zerger, A., 2002. Examining GIS decision utility for natural hazard risk modelling Environ. Model. Softw. 17, 287-294. 